Jurnal Health Sains: p-ISSN: 2723-4339 e-ISSN: 2548-1398

Vol. 2, No. 3, Maret 2021

\title{
HUBUNGAN PENGETAHUAN DAN SIKAP KELUARGA TERHADAP PEMBERANTASAN SARANG NYAMUK DEMAM BERDARAH DENGUE
}

\section{Wawan Kurniawan dan Aat Agustini}

Sekolah Tinggi Ilmu Kesehatan (STIKes) YPIB Majalengka Jawa Barat, Indonesia Email: wawankurniawan.mjl@gmail.com dan aatagustini.mjl@gmail.com

\begin{tabular}{|c|c|}
\hline ARTIKEL INFO & ABSTRACT \\
\hline $\begin{array}{l}\text { Tanggal diterima: } 5 \text { Maret } 2021 \\
\text { Tanggal direvisi: } 15 \text { Maret } 2021 \\
\text { Tanggal disetujui: } 25 \text { Maret } 2021\end{array}$ & $\begin{array}{l}\text { Dengue Haemorrhagic Fever }(D H F) \text { is one of the diseases } \\
\text { with high incidence and prevalence in the world of health, } \\
\text { the highest number of dengue hemorrhagic fever cases }\end{array}$ \\
\hline $\begin{array}{l}\text { Keywords: } \\
\text { knowledge; attitude; family; } \\
\text { dengue hemorrhagic fever }\end{array}$ & $\begin{array}{l}\text { was found in Majalengka District in Cigasong Community } \\
\text { Health Center (CHC Unit) of } 15 \text { cases (13.3\%) This study } \\
\text { aims to determine the relationship between family } \\
\text { knowledge and family attitudes on the eradication of the } \\
\text { breeding of dengue hemorrhagic fever mosquito in the } \\
\text { Work Area of Cigasong CHC Unit Majalengka District in } \\
2018 \text {. The study type was quantitative research with cross } \\
\text { sectional approach. The samples in this study were } \\
\text { families in the Work Area of Cigasong CHC Unit } \\
\text { Majalengka District in } 2018 \text { as many as } 99 \text { people } \\
\text { collected with purposive sampling technique. Data } \\
\text { analysis included univariate analysis with frequency } \\
\text { distribution and bivariate analysis with chi square test. } \\
\text { The result showed that less than half (30.3\%) of families } \\
\text { had poor DHF mosquito breeding eradication, less than } \\
\text { half (46.5\%) of families had poor knowledge and a small } \\
\text { part (20.2\%) of families had negative attitude. There was } \\
\text { a relationship between family knowledge and family } \\
\text { attitudes on the eradication of the breeding of dengue } \\
\text { hemorrhagic fever mosquito in the Work Area of } \\
\text { Cigasong CHC Unit Majalengka District in } 2018 \text {. Health } \\
\text { workers need to improve counseling activities on } \\
\text { eradication of mosquito nests, carry out routine mosquito } \\
\text { eradication programs with abate and fogging, and for } \\
\text { families or communities to eradicate mosquito nests by } \\
\text { burying, draining and recycling water reservoirs so that } \\
\text { they do not become mosquito nests royong, and actively } \\
\text { access information from various media in an effort to } \\
\text { eradicate mosquito nests. }\end{array}$ \\
\hline
\end{tabular}

\begin{abstract}
ABSTRAK
Penyakit Demam Berdarah Dengue (DBD) merupakan salah satu kejadian inkonvensional (KLB) yang masih sering terjadi di dunia saat ini. Kasus DBD terbanyak terjadi di Kabupaten Majalengka yaitu UPTD Puskesmas Cigasong sebanyak 15 kasus (13,3\%). Penelitian ini bertujuan untuk mengetahui hubungan pengetahuan dan sikap keluarga tentang pemberantasan sarang nyamuk
\end{abstract}


Kata Kunci:

pengetahuan; sikap; keluarga; demam berdarah dengue demam berdarah dengue di wilayah kerja UPTD

Puskesmas Cigasong Kabupaten Majalengka Tahun 2018. Jenis penelitian yang digunakan adalah penelitian kuantitatif di Cigasong, Kabupaten Majalenka, pada tahun 2018 sebanyak 99 orang menggunakan teknik auxiliary purpose. Analisis data meliputi analisis univariat menggunakan distribusi frekuensi dan analisis bivariat menggunakan uji chi-square. Hasil penelitian menunjukkan bahwa kurang dari separuh $(30,3 \%)$ rumah tangga yang telah memberantas sarang nyamuk DBD, kurang dari separuh $(46,5 \%)$ rumah tangga yang tidak berpengetahuan, dan sebagian kecil $(20,2 \%)$ rumah tangga yang bersikap negatif. Hubungan pengetahuan keluarga dan sikap keluarga terhadap pemberantasan sarang nyamuk DBD terjadi di wilayah kerja Puskesmas Cigasong Kabupaten Majalenka tahun 2018. Petugas kesehatan perlu meningkatkan kegiatan sosialisasi untuk pemberantasan sarang nyamuk, melaksanakan program pemberantasan nyamuk secara konvensional melalui pengurangan dan pemberantasan kabut, serta membiarkan keluarga atau masyarakat membasmi sarang nyamuk melalui penguburan, drainase dan daur ulang waduk agar tidak terpengaruh oleh kerja sama bersama. menjadi sarang nyamuk, dan aktif memperoleh informasi dari berbagai media pemberantasan sarang nyamuk.
Coresponden Author:

Email: wawankurniawan.mjl@gmail.com Artikel dengan akses terbuka dibawah lisensi

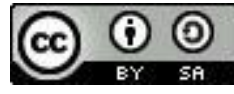

\section{Pendahuluan}

Penyakit zoonosis merupakan masalah kesehatan yang penting dalam perekonomian dunia saat ini. Untuk itu diperlukan pengembangan seperangkat kebijakan, strategi dan rencana penanggulangan penyakit zoonosis pada hewan, obat-obatan, kesehatan masyarakat dan penyehatan lingkungan. Ada banyak ancaman terhadap kesehatan secara global dan lokal. Harus menggunakan pendekatan interdisipliner, interdisipliner, dan interdisipliner untuk merespon ancaman secara profesional (Kemenkes, 2017).

Demam Berdarah Dengue (DBD) adalah penyakit infeksi yang ditandai dengan demam mendadak dan pendarahan dari kulit atau bagian tubuh lainnya, yang dapat menyebabkan syok bahkan kematian. Demam berdarah disebabkan oleh virus dengue dari famili Flaviviridae dan oleh nyamuk Ae. Aegypti: Ae Ayypti masih hidup dan dapat disimpan di air atau sampah rumah tangga, termasuk ban, kaleng, dan wadah air mineral. Air mati dalam vas atau barang bekas lainnya yang dapat menampung air.

Virus Dengue menimbulkan tiga gejala klinis yaitu Demam Virus Dengue (Dfv), Demam Berdarah Dengue (DBD) dan Dengue Shock Syndrome (Dengue Fever Shock Syndrome / DSS). Sindrom syok dengue merupakan penyebab utama kematian pada DB. Virus demam berdarah merusak sistem kekebalan dan membocorkan pembuluh darah. Jika tidak ditangani tepat waktu, akan 
terjadi kegagalan sirkulasi darah. Hematokrit yang meningkat (HCT) adalah awal dari penyakit peredaran darah, dan kegagalan peredaran darah akan diakhiri dengan syok.

Laporan Organisasi Kesehatan Dunia menunjukkan bahwa dalam 50 tahun terakhir, kasus demam berdarah global meningkat 30 kali lipat. Ada sekitar 390 juta infeksi demam berdarah di seluruh dunia setiap tahun, dan tiga perempat pasien demam berdarah berada di kawasan Asia-Pasifik. Indonesia memiliki prevalensi DB tertinggi di Asia Tenggara (> 57\%), dan hampir 70\% kematian disebabkan oleh DB. Jumlah kasus demam berdarah di seluruh dunia mencapai 5\%, dan diperkirakan 25.000 orang meninggal setiap tahun (Wati et al., 2016).

Di Indonesia, DB pertama kali ditemukan di Surabaya dan Jakarta pada tahun 1968. Sejak tahun 1994 telah menyebar ke 27 provinsi di Indonesia, 12 diantaranya berstatus KLB [4]. Saat ini di seluruh provinsi di Indonesia terdapat kasus DB. Incidence rate (IR) atau kasus baru DB di Indonesia terus meningkat dari tahun ke tahun. Angka kejadian DB pada tahun 2017 adalah 41,25 / 100.000 kasus, meningkat 37,2 / 100.000 kasus dibandingkan tahun sebelumnya. IR dari tiga provinsi dengan jumlah kasus tertinggi jauh melebihi target nasional (IR = $55 /$ 100.000), yaitu Bali $(\mathrm{IR}=168.48 /$ 100.000), DKI Jakarta ( $I R=96.18 / 100.000)$ dan Kalimantan Timur $(\mathrm{IR}=92,73)$ / 100.000). Pada tahun 2017, Case Fatality Rate (CFR) nasional adalah 0,7 . Tiga provinsi dengan kasus kematian tertinggi adalah Jamby (2,8\%), Kepulauan Bangka Belitung $(2,7 \%)$ dan Nusa Tenggara Timur (2,2\%).

Prevalensi DBD di Jawa Barat menempati urutan ke 11 di Indonesia. Selama periode 2014-2017 jumlah kasus DB di Jawa Barat mengalami fluktuasi, namun CFR menunjukkan tren yang meningkat. Pada tahun 2014 terdapat 13.971 kasus dan 59 kematian $(\mathrm{CFR}=0,42)$, pada tahun 2015 terdapat 19.742 kasus dan 167 kematian (CFR
= 0,86), pada tahun 2016 terdapat 23.118 kasus, dengan 162 kematian $(0,7)$, dan pada tahun 2017 terdapat 18.116 kasus 178 Kematian $(\mathrm{CFR}=1,36)$. Tiga daerah $/$ kota terpopuler adalah Kota Bandung, Kabupaten Sukhabumi, dan Kabupaten Tasimaraya. Peningkatan DB CFR di Jawa Barat menunjukkan bahwa DB masih menjadi masalah yang belum terselesaikan (Kemenkes, 2017).

Menurut DB, Kabupaten Majaalengka menempati urutan kesepuluh di Jawa Barat, namun prevalensinya terus meningkat dalam tiga tahun terakhir. Bahkan pada tahun 2012, Majaalengka menempati urutan pertama $(5,2 \%)$ dalam database kasus kematian tertinggi di Jawa Barat. Terdapat 184 kematian dan 2 kematian pada tahun 2014 $(\mathrm{CFR}=1,09), 308$ kematian dan 2 kematian $(\mathrm{CFR}=1)$ pada tahun 2015, dan 328 kematian dan 4 kematian pada tahun 2016. Angka fatalitas kasus pada tahun 2016 adalah $1,2 \%$, lebih tinggi dari CFR nasional yang $<1 \%$. Angka survei basis data internal pada tahun 2016 adalah 28 per 100.000 , yang berada di bawah target nasional sebesar 55.100.000.

Di masyarakat saat ini, acara khusus di lingkungan dinas kesehatan (KLB) masih sering terjadi. DBD merupakan penyakit yang disebabkan oleh virus demam berdarah yang ditularkan melalui gigitan nyamuk Aedes aegypti dan Aedes albopictus sehingga menyebabkan gangguan pada pembuluh kapiler dan sistem pembekuan darah sehingga terjadi perdarahan (Kunoli, 2012). DBD ditularkan dari genus Aedes melalui gigitan nyamuk, terutama Aedes aegypti atau Aedes albopictus. DBD dapat terjadi sepanjang tahun dan dapat menyerang semua kelompok umur. Penyakit tersebut berkaitan dengan kondisi lingkungan dan perilaku masyarakat (Kemenkes, 2017).

Berdasarkan faktor-faktor tersebut maka pemerintah telah merumuskan tata cara penanggulangan $\mathrm{DBD}$, salah satunya dengan 
memutus rantai penularan melalui pengendalian vektor DBD. Pengendalian vektor DBD dilakukan dengan menggunakan Sarang Pembunuh Nyamuk (PSN). PSN bertujuan memutus siklus hidup nyamuk dan menjadi media penular DBD. Tujuan utamanya adalah membasmi jentik-jentik nyamuk dan mengubahnya menjadi nyamuk dewasa kelak. Dengan tidak adanya jentik nyamuk maka tidak ada nyamuk dewasa yang berarti tidak ada penyakit vektor DBD (Kemenkes, 2017).

Kegiatan PSN biasanya merupakan semboyan 3M yaitu mengosongkan, menutup dan mengubur waduk. Saat ini, aktivitas 3M telah berkembang menjadi $3 \mathrm{M}$ Plus. Selain $3 \mathrm{M}$, ada tindakan pencegahan lainnya, seperti mengganti air di dalam vas, memperbaiki bak cuci yang tidak licin atau tidak rusak, menutup lubang pada bambu dan membersihkan atau mengeringkan air (seperti tiang atau ember pisang). Tanaman lain) dapat dikeringkan di tempat lain di pekarangan tempat pengumpulan air hujan, dan sebagainya (Kemenkes, 2017).

Perilaku PSN dapat dipengaruhi oleh banyak faktor, termasuk faktor kerentanan, termasuk pengetahuan, sikap, pendidikan, dan nilai. Faktor yang mempengaruhinya adalah fasilitas dan jarak sarana sanitasi, serta faktor pendukung yaitu peran dan informasi petugas kesehatan. Pengetahuan adalah bidang di mana perilaku seseorang dibentuk (Notoatmodjo, 2012). Pengetahuan seseorang yang baik akan melahirkan keyakinan dan sikap yang positif, dan pada akhirnya akan timbul perilaku PSN (Azwar, 2013).

Pada tahun 2016 terdapat 322 kasus DBD di Kabupaten Majalenka, dan kejadian DBD di wilayah tersebut sebesar 27,10 per 100.000 penduduk. Pada tahun 2017 terdapat 112 kasus DBD di Kabupaten Majalenka dimana UPTD Puskesmas Cigasong memiliki jumlah terbanyak yaitu 15 kasus (13,3\%), sedangkan UPTD Puskesmas Sukahaji hanya 4 kasus $(3,57 \%)$ (Amalia, 2017). Pada tahun
2018 jumlah rumah tangga di wilayah kerja Puskesmas Cigasong Kabupaten Majalengka sebanyak 9.512 (UPTD Puskesmas Cigasong, 2018). Pada UPTD Puskesmas Cigasong 2018 Wilayah Kerja Kabupaten Majalenka memahami hubungan pengetahuan keluarga dengan sikap memberantas sarang nyamuk DBD.

\section{Metode Penelitian}

Penelitian ini merupakan penelitian kuantitatif dengan menggunakan metode cross sectional atau desain penelitian. Subjek penelitian adalah 9.512 kepala keluarga (kepala rumah tangga), dan diambil sampel sebanyak 99 orang dengan menggunakan teknologi target. Analisis data meliputi analisis univariat menggunakan distribusi frekuensi dan adopsi bivariat. Analisis gas. Tes kotak-kotak.

\section{Hasil dan Pembahasan}

\section{A. Hasil Penelitian}

a. Gambaran Pemberantasan Sarang Nyamuk Demam Berdarah Dengue di Wilayah Kerja UPTD Puskesmas Cigasong Kabupaten Majalengka Tahun 2019

Tabel 1

Distribusi Frekuensi Pemberantasan Sarang Nyamuk Demam Berdarah Dengue di Wilayah Kerja UPTD Puskesmas Cigasong Kabupaten Majalengka Tahun 2019

\begin{tabular}{|c|c|c|c|}
\hline $\begin{array}{c}\mathbf{N} \\
\mathbf{0}\end{array}$ & $\begin{array}{c}\text { Pemberantasa } \\
\text { n Sarang } \\
\text { Nyamuk DBD }\end{array}$ & $\begin{array}{c}\text { Frekuens } \\
\text { i } \\
\text { (f) }\end{array}$ & $\begin{array}{c}\text { Persentas } \\
\text { e } \\
(\%)\end{array}$ \\
\hline 1 & Kurang & 30 & 30.3 \\
\hline 2 & Baik & 69 & 69.7 \\
\hline & Jumlah & 99 & 100.0 \\
\hline
\end{tabular}

Dari Tabel 1 terlihat bahwa kurang dari 30 orang $(30,3 \%)$ yang telah memberantas sarang nyamuk DBD, dan 69 orang $(69,7 \%)$ adalah orang baik. Hal ini menunjukkan bahwa pada tahun 2019 kurang dari separuh rumah tangga $(30,3 \%)$ di wilayah kerja UPTD Puskesmas 
Cigasong Universitas Bupati Majalenka masih kurang memiliki kesempatan untuk memberantas sarang nyamuk demam berdarah.

b. Gambaran Pengetahuan Keluarga di Wilayah Kerja UPTD Puskesmas Cigasong Kabupaten Majalengka Tahun 2019

Tabel 2

Distribusi Frekuensi Pengetahuan

Keluarga di Wilayah Kerja UPTD

Puskesmas Cigasong Kabupaten Majalengka Tahun 2019

\begin{tabular}{|c|c|}
\hline No & $\begin{array}{c}\text { Pengetahuan } \\
\text { Keluarga }\end{array}$ \\
\hline 1 & Kurang baik \\
\hline \multirow[t]{12}{*}{2} & Baik \\
\hline & Jumlah \\
\hline & Berdasarkan Tabel 2 dapat \\
\hline & diketahui bahwa 46 orang $(46,5 \%)$ \\
\hline & berpengetahuan kurang, dan sebanyak \\
\hline & 53 orang $(53,5 \%)$ berpengetahuan baik. \\
\hline & $\begin{array}{l}\text { Hal ini menunjukkan bahwa pada tahun } \\
2019 \text {, kurang dari separuh }(46,5 \%)\end{array}$ \\
\hline & keluarga di wilayah kerja UPTD \\
\hline & Cigasong Universitas \\
\hline & Bupati Majalenka \\
\hline & Gambaran Sikap Keluarga di Wilayah \\
\hline & $\begin{array}{l}\text { Kerja UPTD Puskesmas Cigasong } \\
\text { Kabupaten Majalengka Tahun } 2019 .\end{array}$ \\
\hline
\end{tabular}

Tabel 3

Distribusi Frekuensi Sikap Keluarga di Wilayah Kerja UPTD Puskesmas Cigasong Kabupaten Majalengka Tahun 2019

\begin{tabular}{cccc}
\hline No & $\begin{array}{c}\text { Sikap } \\
\text { Keluarga }\end{array}$ & $\begin{array}{c}\text { Frekuensi } \\
\text { (f) }\end{array}$ & $\begin{array}{c}\text { Persentase } \\
(\mathbf{\%})\end{array}$ \\
\hline 1 & Negatif & 20 & 20.2 \\
2 & Positif & 79 & 79.8 \\
\hline & Jumlah & $\mathbf{9 9}$ & $\mathbf{1 0 0 . 0}$ \\
\hline
\end{tabular}

Terlihat dari Tabel 3 bahwa 20 keluarga yang bersikap negatif $(20,2 \%)$ dan 79 orang $(79,8 \%)$ yang bersikap positif. Hal ini menunjukkan bahwa sebagian kecil keluarga $(20,2 \%)$ di wilayah kerja UPTD Puskesmas Cigasong Kabupaten Majalenka pada tahun 2019 bersikap negatif.

d. Hubungan Pengetahuan Keluarga terhadap Pemberantasan Sarang Nyamuk Demam Berdarah Dengue di Wilayah Kerja UPTD Puskesmas Cigasong Kabupaten Majalengka Tahun 2019

\section{Tabel 4}

Hubungan antara Pengetahuan

Keluarga terhadap Pemberantasan

Sarang Nyamuk Demam Berdarah

Dengue di Wilayah Kerja UPTD

Puskesmas Cigasong Kabupaten Majalengka Tahun 2019

\begin{tabular}{|c|c|c|c|c|c|c|c|c|}
\hline \multirow[t]{3}{*}{ No } & \multirow[t]{3}{*}{$\begin{array}{l}\text { Pengetah } \\
\text { uan } \\
\text { Keluarga }\end{array}$} & \multicolumn{4}{|c|}{$\begin{array}{c}\text { Pemberantasan } \\
\text { Sarang Nyamuk } \\
\text { Demam Berdarah } \\
\text { Dengue } \\
\end{array}$} & \multirow{2}{*}{\multicolumn{2}{|c|}{ Jumlah }} & \multirow[t]{3}{*}{ value } \\
\hline & & \multicolumn{2}{|c|}{ Kurang } & \multicolumn{2}{|c|}{ Baik } & & & \\
\hline & & $\mathbf{F}$ & $\%$ & f & $\%$ & $\mathbf{F}$ & $\%$ & \\
\hline 1 & $\begin{array}{l}\text { Kurang } \\
\text { baik }\end{array}$ & 22 & 74,8 & 24 & 52,2 & 46 & 100 & \\
\hline \multirow[t]{2}{*}{2} & Baik & 8 & 15,1 & 45 & 84,9 & 53 & 100 & 000 \\
\hline & Jumlah & 30 & 30,3 & 69 & 69,7 & 99 & 100 & \\
\hline
\end{tabular}

Berdasarkan data pada Tabel 4 dapat dipahami bahwa proporsi rumah tangga yang memiliki pengetahuan buruk tentang pemberantasan sarang nyamuk DBD kurang dari 22 (74,8\%), sedangkan proporsi rumah tangga yang memiliki pengetahuan baik tentang pemberantasan nyamuk DBD kurang dari 8 sarang. $(15,1 \%)$. Hal ini menunjukkan bahwa sarang nyamuk dengue yang lebih sedikit telah dimusnahkan pada keluarga yang kurang berpengetahuan.

Hasil perhitungan statistik uji chisquare pada $\alpha=0,05$ diperoleh nilai $\square$ $=0,000$ (nilai $\square<\alpha$ ), sehingga hipotesis nol ditolak yang berarti ada hubungan antara pengetahuan keluarga untuk memberantas demam berdarah 
dengue UPTD Puskesmas. Sarang Nyamuk Kabupaten Cigasong, Majalenka 2019.

e. Hubungan Sikap Keluarga terhadap Pemberantasan Sarang Nyamuk Demam Berdarah Dengue di Wilayah Kerja UPTD Puskesmas Cigasong Kabupaten Majalengka Tahun 2019

\section{Tabel 5}

Hubungan antara Sikap Keluarga terhadap Pemberantasan Sarang Nyamuk Demam Berdarah Dengue di Wilayah Kerja UPTD Puskesmas Cigasong Kabupaten Majalengka

Tahun 2019

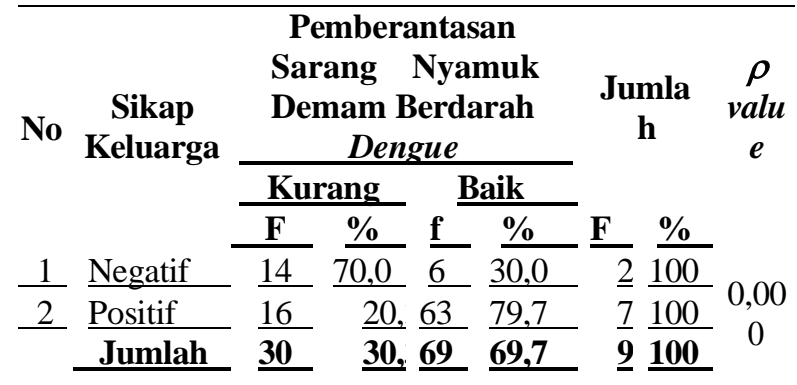

Berdasarkan data pada Tabel 5 terlihat bahwa kurang dari 14 orang (70,0\%) rumah tangga yang memiliki sikap negatif terhadap pemberantasan kelambu DBD, sedangkan 14 orang memiliki sikap positif terhadap pemberantasan nyamuk DBD. jaring. Kurang dari 16 orang $(20,3 \%)$. Hal ini menunjukkan bahwa demam berdarah sedikit banyak telah menghilangkan sarang nyamuk di rumah tangga yang negatif.

Bila $\alpha=0,05$ maka hasil perhitungan statistik uji chi-square adalah $\neq 0,000$ (nilai $<\alpha$ ), sehingga hipotesis nol ditolak yang artinya ada hubungan antara sikap keluarga terhadap pemberantasan nyamuk demam berdarah dengue. Bersarang di wilayah kerja UPTD Puskesmas
Cigasong Kabupaten Majalenka tahun 2019.

\section{B. Pembahasan}

1. Gambaran Pemberantasan Sarang Nyamuk Demam Berdarah Dengue di Wilayah Kerja UPTD Puskesmas Cigasong Kabupaten Majalengka Tahun 2019

Berdasarkan hasil penelitian, pada tahun 2019 kurang dari separuh (30,3\%) rumah tangga di wilayah kerja UPTD Puskesmas Maya Lunka Regent University Cigasong memiliki peluang yang lebih kecil dalam pemberantasan sarang nyamuk DBD. Masih ada alasan mengapa sebagian keluarga kekurangan kelambu untuk memberantas DBD. Hal ini mungkin karena keluarga belum mengetahui cara menghilangkan kelambu, sehingga tidak peduli pencegahan demam berdarah dengan cara melepas kelambu. Membasmi sarang nyamuk dengan benar dapat menyebabkan nyamuk berkembang biak dan terjangkit demam berdarah. Di area belajar masih banyak pekarangan depan rumah, dimana masih terdapat barang bekas yang mungkin menjadi genangan air, sebagian kecil bagian luar rumah masih tergenang, wastafel tidak pernah dibersihkan, dan air / saluran komunikasi sangat buruk. Air limbah kurang bersih. Sementara itu, di dalam ruangan, sebagian besar narasumber tidak menggunakan kain kasa, tidak menggantung pakaian, tidak menggunakan kelambu, sebagian kecil tidak memiliki penerangan dan ventilasi yang memadai, serta tidak menggunakan pengusir nyamuk dan pengawet.

Hasil penelitian ini lebih rendah dibanding hasil penelitian (Ardiansyah, 2013) menunjukkan bahwa di Kelurahan Anawai, Kecamatan Wua-wua Kendari yang berperilaku PSN kurang baik sebsar 42,5\%. Juga hasil penelitian (Simatupang et al., 2012) di Kelurahan Paniki Bawah 
Kecamatan Mapanget Kota Manado menunjukkan bahwa tindakan pemberantasan sarang nyamuknya kurang baik sebesar $30,6 \%$.

Demam Berdarah Dengue (DBD) adalah penyakit menular yang ditandai dengan panas (demam) dan disertai dengan perdarahan (Kemenkes, 2017). DBD merupakan penyakit menular yang disebabkan oleh virus demam berdarah yang ditularkan oleh nyamuk Aedes aegypti dan Aedes albopictus. Ditandai dengan demam mendadak selama 2 sampai 7 hari tanpa penyebab yang jelas, lemas atau lesu, gelisah, mulas, dan berdarah. Tanda. Kulit berupa bercak, perdarahan (petechie), memar (tinea tangan dan kaki) atau ruam (purpura), kadang mimisan, disentri, muntah darah, hilang kesadaran atau syok (Hanim et al., 2013).

DBD ditularkan dari genus Aedes melalui gigitan nyamuk, terutama Aedes aegypti atau Aedes albopictus. DBD dapat terjadi sepanjang tahun dan dapat menyerang semua kelompok umur. Penyakit tersebut berkaitan dengan kondisi lingkungan dan perilaku masyarakat (Kemenkes, 2017).

Salah satu upaya pemberantasan perkembangbiakan nyamuk adalah PSN. Kegiatan PSN biasanya merupakan semboyan 3M yaitu mengosongkan, menutup dan mengubur waduk. Saat ini aktivitas 3M telah berkembang menjadi $3 \mathrm{M}$ Plus. Selain 3M, ada tindakan pencegahan tambahan, seperti mengganti air di vas, memperbaiki bak cuci piring yang tidak licin atau tidak rusak, menutup lubang pada irisan bambu, dan membersihkan atau mengeringkan tempat yang bisa menampung air (seperti batang pisang atau tanaman lain) dikeringkan di tempat lain di pekarangan tempat penampungan air hujan, dll. (Kemenkes, 2017).
Perilaku PSN dapat dipengaruhi oleh berbagai faktor, antara lain faktor kerentanan yang meliputi pengetahuan, sikap, pendidikan, dan nilai. Faktor penyebabnya adalah fasilitas dan jarak sarana sanitasi, serta faktor pendukung yaitu peran dan informasi petugas kesehatan. Pengetahuan adalah bidang di mana perilaku seseorang dibentuk (Notoatmodjo, 2012). Pengetahuan seseorang yang baik akan melahirkan keyakinan dan sikap yang positif, dan pada akhirnya akan timbul perilaku PSN (Azwar, 2013).

Masih minimnya keluarga yang memberantas sarang nyamuk DBD.Oleh karena itu, petugas kesehatan perlu meningkatkan kegiatan promosi dengan cara yang lebih menarik, seperti penggunaan visual display untuk menghilangkan sarang nyamuk, pembagian leaflet, dan di lokasi-lokasi strategis terkait pemberantasan sarang nyamuk. dipasang sehingga mudah dipahami dan dipahami oleh masyarakat, dan program anti-nyamuk rutin, seperti program mitigasi dan penghapusan kabut, juga dilakukan. Bagi keluarga atau masyarakat perlu dilakukan pemberantasan sarang nyamuk di rumahnya masing-masing dan melakukan kegiatan gotong royong secara rutin untuk mencegah berkembang biaknya nyamuk.

2. Gambaran Pengetahuan Keluarga di Wilayah Kerja UPTD Puskesmas Cigasong Kabupaten Majalengka Tahun 2019

Berdasarkan hasil penelitian, penelitian menunjukkan bahwa kurang dari separuh $(46,5 \%)$ rumah tangga di wilayah kerja UPTD Puskesmas Cigasong Kabupaten Majalenka pada tahun 2019 kurang berpengetahuan. Masih ada beberapa keluarga yang kurang berpengetahuan karena belum terpapar informasi, atau mungkin belum mendapat 
konsultasi dari petugas, namun masih kurang paham, seperti harus menguras bak mandi, menutup tempat pengisian air, dan menjaga kebersihan lingkungan, seperti hasil perkembangbiakan nyamuk dengan mudah.

Hasil penelitian ini lebih tinggi dibanding dengan hasil penelitian (Simatupang et al., 2012) di Kelurahan Paniki Bawah Kecamatan Mapanget Kota Manado menunjukkan bahwa pengetahuan yang kurang sebesar $40,6 \%$. Juga dengan hasil penelitian (Waruwu et al., 2015) di Kelurahan Pegirian Surabaya menunjukkan bahwa responden yang berpengetahuan kurang sebesar 37,9\%.

Pengetahuan adalah hasil dari mengetahui dan terjadi setelah orang melakukan tindakan terhadap suatu objek. Sensasi terjadi melalui indera manusia yaitu penglihatan, pendengaran, pengecapan dan peraba. Kebanyakan pengetahuan manusia diperoleh melalui mata dan telinga. Pengukuran pengetahuan dapat dilakukan dengan wawancara atau menanyakan objek penelitian atau angket tentang isi materi yang akan diukur (Notoatmodjo, 2012).

Ilmu dalam Kamus Besar Bahasa Indonesia (2012) adalah segala sesuatu yang diketahui secara bijak, atau segala sesuatu yang diketahui. Pada saat yang sama, tidak tahu berarti seseorang yang tidak tahu apa yang terjadi di sekitarnya. Menurut (Kevin et al., 2011), Pengetahuan adalah proses pengalaman khusus, dirancang untuk menciptakan perubahan konstan dalam perilaku dan pemikiran. Menurut (Notoatmodjo, 2012) Perilaku berbasis pengetahuan akan lebih tahan lama dibandingkan perilaku nonpengetahuan.

Beberapa keluarga masih kurang pengetahuannya, oleh karena itu petugas kesehatan perlu menggunakan cara yang lebih menarik dalam memberikan informasi atau penyuluhan agar masyarakat lebih mudah menerima informasi tersebut. Selain memberikan informasi, mereka juga melakukan kunjungan rumah dan juga dapat mengurangi penyakit yang dideritanya secara rutin. . Menjadikan keluarga dan masyarakat lebih giat mengakses informasi dari berbagai media (elektronik dan media cetak) untuk menimba ilmu tentang cara pemberantasan sarang nyamuk DBD.

3. Gambaran Sikap Keluarga di Wilayah Kerja UPTD Puskesmas Cigasong Kabupaten Majalengka Tahun 2019

Berdasarkan hasil penelitian, penelitian menunjukkan bahwa sebagian kecil keluarga $(20,2 \%)$ di wilayah kerja UPTD Puskesmas Cigasong Kabupaten Majalenka tahun 2019 memiliki sikap negatif. Beberapa keluarga masih memiliki sikap negatif, yang mungkin disebabkan oleh kurangnya pemahaman, seperti mengosongkan bak mandi sebulan sekali atau mengeringkan bak mandi saat kotor, membuang sampah sembarangan, dan menggantung banyak pakaian di kastor. Demam sangat umum terjadi, sehingga keluarga tidak dapat menghilangkan kelambu dengue dengan baik.

Hasil penelitian ini lebih tinggi dibanding dengan hasil penelitian (Makornkan, 2015) di Thailand menunjukkan bahwa sikap responden yang negatif sebesar $40,6 \%$ dan hasil penelitian (Ardiansyah, 2013) menunjukkan bahwa di Kelurahan Anawai, Kecamatan Wuawua Kendari yang bersikap negatif sebesar 30,6\%. Demikian juga hasil penelitian (Shanti, 2012) di Desa Dalung Kecamatan Kuta Utara menunjukkan bahwa sikap masyarakat yang negatif sebesar 39,6\%.

Sikap adalah reaksi atau respons tertutup seseorang terhadap suatu rangsangan atau objek. Kinerja sikap tidak bisa langsung dilihat, tetapi hanya bisa 
dijelaskan sebelum perilaku tertutup (Daryono, 2013). Sikap merupakan penentu perilaku yang penting. Sikap seseorang akan menggambarkan perilaku orang tersebut. Berdasarkan sikap seseorang, orang akan dapat memprediksi bagaimana orang tersebut akan merespon masalah atau situasi yang dihadapinya. Oleh karena itu, dalam situasi ideal yang normal, seseorang dapat melihat dari sikapnya gambaran tentang kemungkinan tindakan atau perilaku yang akan diambil dalam menanggapi masalah atau situasi yang akan ia angkat (Ali et al., 2014).

Menurut (Wawan, 2011) dipercaya bahwa sikap dapat digunakan sebagai hasil evaluasi objek sikap, yang diekspresikan dalam proses kognitif, emosional (emosi) dan perilaku. Seperti yang dapat dilihat dari definisi di atas, sikap biasanya terdiri dari komponen kognitif (konsep biasanya dikaitkan dengan dialog dan pembelajaran), perilaku (kecenderungan untuk mempengaruhi tanggapan yang sesuai dan tidak tepat), dan emosi (mengarah ke tanggapan yang konsisten).

Masih adanya keluarga yang memiliki sikap negatif terhadap pemberantasan sarang nyamuk DBD, oleh karena itu petugas kesehatan harus menggunakan cara-cara yang mudah dipahami dan baik untuk memberikan arahan atau informasi kepada masyarakat agar dapat mengembangkan sikap positif di masyarakat. Bagi keluarga dan masyarakat perlu rutin melakukan kegiatan gotong royong untuk membentuk sikap masyarakat yang positif terhadap sarang nyamuk DBD.

4. Hubungan Pengetahuan Keluarga terhadap Pemberantasan Sarang Nyamuk Demam Berdarah Dengue di Wilayah Kerja UPTD Puskesmas Cigasong Kabupaten Majalengka Tahun 2019

Berdasarkan hasil penelitian menunjukkan bahwa terdapat hubungan antara pengetahuan keluarga tentang pemberantasan sarang nyamuk demam berdarah dengue di wilayah kerja UPTD Puskesmas Cigasong Kabupaten Majalengka tahun 2019. Adanya hubungan ini dapat memperoleh manfaat dari pengetahuan pencegahan demam berdarah dengan membunuh sarang nyamuk dan akan mendorong tindakan bermanfaat seperti drainase, penguburan dan penutupan, serta manfaat lain seperti penggantian vas secara berkala dan perbaikan drainase.

Hasil penelitian sejalan dengan hasil penelitian (Ardiansyah, 2013) menunjukkan bahwa terdapat hubungan antara pengetahuan kepala keluarga $(\rho=$ 0,012) terhadap pengendalian vektor penyakit demam berdarah dengue di Kelurahan Anawai, Kecamatan Wua-wua Kendari. Juga hasil penelitian (Shanti, 2012) menunjukkan bahwa ada pengaruh pengetahuan masyarakat terhadap aktivitas pemberantasan sarang nyamuk di Desa Dalung Kecamatan Kuta Utara $(\mathrm{p}=$ 0,0012).

Hasil penelitian ini sejalan dengan penelitian (Simatupang et al., 2012) di Kelurahan Paniki Bawah Kecamatan Mapangit Kota Manado menunjukkan adanya hubungan antara pengetahuan dengan perilaku pemberantasan sarang nyamuk DBD ( $p=0,002)$. Juga hasil penelitian (Waruwu et al., 2015) di Kelurahan Pegirian Surabaya menunjukkan bahwa ada hubungan antara pengetahuan dengan perilaku ibu dalam pemberatasan sarang nyamuk demam berdarah dengue $(\mathrm{p}=0,001)$.

Hasil penelitian ini sejalan dengan teori sebagai berikut: Pengetahuan berkaitan erat dengan perilaku individu yang menggunakan layanan kesehatan. Dengan kekayaan ilmu yang dimilikinya, ia akan lebih memperhatikan kondisi kesehatan dan berusaha mengoptimalkan 
pelayanan kesehatan yang ada di lingkungannya (Benuf \& Azhar, 2020).

Hasil penelitian ini sejalan dengan teori berikut: Pengetahuan atau kognisi merupakan bidang yang sangat penting yang dibentuk oleh perilaku seseorang (perilaku eksplisit), dan perilaku berbasis pengetahuan lebih tahan lama dibandingkan perilaku non-pengetahuan (Notoatmodjo, 2012). Pemahaman aktif masyarakat tentang DBD dan cara pencegahannya akan mendorong warga untuk memberantas sarang nyamuk dalam kehidupan sehari-hari, sehingga DBD dapat dicegah. Secara khusus, perilaku ibu-ibu yang memiliki motivasi tinggi untuk memberantas kelambu DBD diharapkan dapat memberikan contoh yang baik bagi ibu-ibu yang kurang memiliki motivasi pemberantasan kelambu DBD melalui kegiatan 3M (Waruwu et al., 2015).

Ada keterkaitan antara pengetahuan dan pemberantasan sarang nyamuk DBD.Oleh karena itu, petugas kesehatan perlu menggunakan metode yang lebih menarik dalam memberikan informasi atau penyuluhan agar masyarakat dapat lebih mudah menerima informasi tersebut. Selain memberikan informasi, mereka juga melakukan kunjungan rumah dan juga Informasi harus diberikan secara teratur. Meringankan. Menjadikan keluarga dan masyarakat lebih giat mengakses informasi dari berbagai media (elektronik dan media cetak) untuk menimba ilmu tentang cara pemberantasan sarang nyamuk DBD.

5. Hubungan Sikap Keluarga terhadap Pemberantasan Sarang Nyamuk Demam Berdarah Dengue di Wilayah Kerja UPTD Puskesmas Cigasong Kabupaten Majalengka Tahun 2019

Berdasarkan hasil penelitian menunjukkan bahwa terdapat hubungan antara sikap keluarga dalam pemberantasan sarang nyamuk demam berdarah dengue di wilayah kerja UPTD Puskesmas Cigasong Kabupaten Majalenka tahun 2019. Hubungan ini dapat dijelaskan sebagai menjaga sikap positif dan meyakini bahwa demam berdarah dapat dicegah dengan menghilangkan sarangnya.

Hasil penelitian ini sejalan dengan hasil penelitian (Ardiansyah, 2013) menunjukkan bahwa terdapat hubungan antara sikap kepala keluarga $(\rho=0,017)$ terhadap pengendalian vektor penyakit demam berdarah dengue di Kelurahan Anawai, Kecamatan Wua-wua Kendari. Juga dengan hasil penelitian (Shanti, 2012) di Desa Dalung Kecamatan Kuta Utara menunjukkan bahwa ada pengaruh sikap masyarakat terhadap aktivitas pemberantasan sarang nyamuk $(\mathrm{p}=$ 0,0012). Demikian juga dengan hasil penelitian (Simatupang et al., 2012) menunjukkan bahwa ada hubungan antara sikap dengan tindakan pemberantasan sarang nyamuk demam berdarah dengue di Kelurahan Paniki Bawah Kecamatan Mapanget Kota Manado.

Hasil penelitian ini sejalan dengan teori bahwa sikap merupakan determinan penting dari perilaku. Sikap seseorang akan menggambarkan perilaku orang tersebut. Berdasarkan sikap seseorang, orang akan dapat memprediksi bagaimana orang tersebut akan merespon masalah atau situasi yang dihadapinya. Oleh karena itu, dalam keadaan ideal normal, tindakan atau perilaku yang mungkin diambil untuk menanggapi masalah akan dijelaskan (Benuf \& Azhar, 2020). Hasil penelitian ini juga sejalan dengan teori bahwa sikap merupakan salah satu faktor pembentuk perilaku, karena sikap menghasilkan nilai positif atau negatif, yang juga dapat mempengaruhi perilaku positif maupun negatif. Semakin baik sikap seseorang, 
semakin baik perilakunya, begitu pula sebaliknya (Azwar, 2013).

Ada keterkaitan antara sikap dan pemberantasan sarang nyamuk demam berdarah dengue. Oleh karena itu petugas kesehatan harus menggunakan cara-cara yang mudah dipahami dan baik untuk memberikan arahan atau informasi kepada masyarakat agar muncul sikap yang positif di masyarakat. Bagi keluarga dan masyarakat, perlu dilakukan kegiatan gotong royong secara rutin untuk membentuk sikap masyarakat yang positif dalam pemberantasan kelambu DBD.

\section{Kesimpulan}

Hasil penelitian menyimpulkan bahwa pertama-tama pada tahun 2019, kurang dari separuh $(30,3 \%)$ rumah tangga di wilayah kerja UPTD Puskesmas Cigasong Universitas Bupati Majalenka, saat ini belum ada rumah tangga yang melakukan pemberantasan sarang nyamuk demam berdarah. Kedua, pada tahun 2019 kurang dari separuh (46,5\%) keluarga di wilayah kerja UPTD Puskesmas Cigasong Universitas Bupati Majalenka kurang berpengetahuan. Ketiga, pada tahun 2019, sejumlah kecil keluarga (20,2\%) di wilayah kerja UPTD Puskesmas Cigasong Kabupaten Majalenka bersikap negatif. Keempat, tahun 2019 ada hubungan antara pengetahuan keluarga di wilayah kerja UPTD Puskesmas Cigasong Kabupaten Majalenka dengan pemberantasan sarang nyamuk DBD. Kelima, ada keterkaitan antara sikap keluarga terhadap pemberantasan perdarahan demam berdarah dengue. Sarang nyamuk demam tinggi bersarang di wilayah kerja UPTD Puskesmas Cigasong Kabupaten Majalengka tahun 2019.

\section{BIBLIOGRAFI}

Ali, M. N., Xiong, J., Flynn, S., Tao, J., Gibson, Q. D., Schoop, L. M., Liang, T., Haldolaarachchige, N., Hirschberger, M., \& Ong, N. P. (2014). Large, NonSaturating Magnetoresistance In Wte 2. Nature, 514(7521), 205-208.

Amalia, M. (2017). Hubungan Tingkat Pengetahuan Dan Sikap Dengan Kinerja Kader Posyandu Dalam Evaluasi Peningkatan Berat Badan Balita Di Posyandu Desa Cidenok Wilayah Kerja Uptd Puskesmas Sumberjaya Kabupaten Majalengka Tahun 2017. Jurnal Kampus Stikes Ypib Majalengka, 5(11), 23-32.

Ardiansyah, A. (2013). Meningkatkan Hasil Belajar Pada Materi Pokok Hidrokarbon Melalui Model Pembelajaran Kooperatif Tipe Ttw (Think Talk Write) Bermuatan Karakter Siswa Kelas X-4 Sman 6 Banjarmasin. Quantum: Jurnal Inovasi Pendidikan Sains, 4(1).

Azwar, B. (2013). Analisis Faktor-Faktor Yang Mempengaruhi Niat Kewirausahaan (Entrepreneurial Intention)(Studi Terhadap Mahasiswa Universitas Islam Negeri Suska Riau). Menara, 12(1), 12-22.

Benuf, K., \& Azhar, M. (2020). Metodologi Penelitian Hukum Sebagai Instrumen Mengurai Permasalahan Hukum Kontemporer. Gema Keadilan, 7(1), 2033.

Daryono. (2013). Analisis Perilaku Masyarakat. Terhadap Angka Bebas Jentik Dan Demam Berdarah Dengue Di Kecamatan. Pekanbaru Kota Riau. Jurnal Ilmu Lingkungan, 5(1).

Hanim, C., Yusiati, L. M., Cahyanto, M. N. U. R., \& Wibowo, A. L. I. (2013). Mutagenic Improvement Of Xylanase Production From Xylanolytic Bacteria And Its Phylogenetic Analysis. Microbiology Indonesia, 7(2), 2. 
Kemenkes. (2017). Informasi Kementrian Kesehatan Ri. 2014. Situasi Dan Analisis Lanjut Usia.

Kevin, M., Ong, W. L., Lee, G. H., \& Ho, G. W. (2011). Formation Of Hybrid Structures: Copper Oxide Nanocrystals Templated On Ultralong Copper Nanowires For Open Network Sensing At Room Temperature. Nanotechnology, 22(23), 235701.

Kunoli, F. J. (2012). Asuhan Keperawatan Penyakit Tropis. Trans Info Media. Jakarta.

Makornkan. (2015). Knowledge, Attitude And Practice Of Dengue Fever Prevention Among The Villagers Of Moo 1 Baan Klongsai, Nhongyangsuea Subdistrict, Muaklek District, Saraburi Province, Thailand. Institute Press, 12(2).

Notoatmodjo, S. (2012). Metodologi Penelitian Kesehatan.

Shanti, N. I. (2012). Pengaruh Pengetahuan Dan Sikap Masyarakat Tentang Dbd
Terhadap Aktivitas Pemberantasan Sarang Nyamuk Di Desa Dalung Kecamatan Kuta Utara Tahun 2012. Jurnal Kesehatan Lingkungan, 4(2), 14.

Simatupang, H., Nata, A., \& Herlina, N. (2012). Studi Isolasi Dan Rendemen Lignin Dari Tandan Kosong Kelapa Sawit (Tkks). Jurnal Teknik Kimia Usu, I(1), 20-24.

Waruwu, A. F., Bayupati, I. P. A., \& Putra, I. K. G. D. (2015). Augmented Reality Mobile Application Of Balinese Hindu Temples: Dewataar. International Journal Of Computer Network And Information Security, 7(2), 59.

Wati, N. W. K. W., Astuti, S., Sari, L. K., Borneo, S. H., \& Borneo, A. S. H. (2016). Hubungan Pengetahuan Dan Sikap Orang Tua Tentang Upaya Pencegahan Dengan Kejadian Demam Berdarah Dengue (Dbd) Pada Anak Di Rsud Banjarbaru Tahun 2015. Jurnal Kesehatan Indonesia, 6(2).

Wawan, A. Dan D. M. (2011). Teori Dan Pengukuran Pengetahuan, Sikap, Dan. Perilaku Manusia. Nuha Medika. 